\title{
Kepentingan Simbol Salib dalam Tradisi Teologi Agama Kristian
}

\author{
Muhammad Syahmi Farhan Ab Majid \\ Universiti Kebangsaan Malaysia, syahmifarhan16@yahoo.com \\ Indriaty Ismail \\ Universiti Kebangsaan Malaysia, indriaty@ukm.edu.my
}

\begin{abstract}
Abstrak
Simbol salib di anggap sebagai simbol yang penting dan signifikan dalam agama Kristian. Ini kerana, menurut kepercayaan Kristian di sebalik simbol salib tersirat makna teologi yang dapat memberi impak kepada spiritual serta kehidupan mereka. Justeru, kajian ini membincangkan apakah konsep simbol salib dalam agama Kristian dan mengenal pasti hubungannya dengan doktrin penebusan dosa serta penyelamatan. Maklumat yang diperolehi adalah secara kualitatif iaitu melalui kaedah reka bentuk analisis kandungan yang melibatkan bahan bacaan seperti buku-buku, jurnal, artikel, tesis dan kertas kerja. Kajian mendapati bahawa dari perspektif agama Kristian, simbol salib memiliki makna serta konsep teologi iaitu sebagai lambang pengorbanan, kejayaan, kasih sayang dari Tuhan, pendamaian dan penyelamatan. Dalam tradisi teologi Kristian, konsep-konsep tersebut dikenali sebagai teologi salib. Selain itu, simbol salib mempunyai kaitan yang rapat dan merupakan tulang belakang bagi doktrin penebusan dosa serta penyelamatan. Sarjanasarjana Kristian berpandangan bahawa kematian Jesus Christ di atas tiang salib merupakan salah satu daripada rancangan Tuhan untuk menebus dosa serta menyelamatkan manusia. Senario ini menunjukkan bahawa tanpa salib atau peristiwa penyaliban, maka sudah pasti kedua-dua doktrin tersebut tidak dapat dilaksanakan, malah agama Kristian itu sendiri mungkin tidak akan wujud sebagaimana yang terlihat pada hari ini.
\end{abstract}

Kata kunci: simbol salib, teologi salib, penebusan dosa, penyelamatan

\section{An Analysis of the Importance of the Cross in Christian Theology Tradition}

\section{Abstract}

Cross is considered as an important and significant symbol in Christian religion. This is because they believe there are hidden theological meaning that can give something to their spiritual and their lives. Thus, this finding discussed on what is the concept of cross as symbol is in Christian religion focusing more on the relationship of sin redemption (the atonement doctrine) and salvation. Information is gathered qualitatively which by analysing content that involved reading materials 
for instance books, journals, articles, thesis and paperworks. From Christian point of view, the symbol portrays sacrification, triumph, compassionate, reconciliation and salvation. In Christian theology tradition, these concepts are known as theology of the cross. Furthermore, the cross symbol has interconnection and very important with the atonement doctrine and salvation. Christian scholars believe that the death of Jesus Christ on the cross is one of god's planning to redeem sins and to save people. This means if the cross or crucifixion did not happened, both of the doctrines can not be implemented. Plus, the Christian religion itself maybe does not exist as can be seen as today.

Keywords: the Cross symbol, the Cross theology, atonement, salvation

\section{Pendahuluan}

Bagi sesetengah agama, simbol merupakan bahagian yang penting dan memiliki peranannya yang tersendiri dalam kehidupan manusia. Antaranya simbol dijadikan sebagai lambang bagi sesebuah agama, alat sembahan, perhiasan, perantaraan dan sebagainya. Selain itu, pada keadaan tertentu simbol juga memiliki rahsia serta makna tersirat yang dapat menyentuh dimensi kerohanian serta jiwa manusia. sebagai contoh simbol salib yang merupakan simbol utama dan lambang bagi agama Kristian.

Sekiranya diteliti, dalam agama Kristian simbol salib bukan sahaja merujuk kepada simbol atau lambang bagi gereja semata, namun ia turut digunakan dalam aktiviti peribadatan dan pada masa yang sama ia menjadi sebahagian daripada perbahasan yang melibatkan teologi, psikologi, falsafah dan kajian agama. Justeru itu, sejajar dengan arus perkembangan ilmu dan pendidikan, penelitian terhadap simbol salib perlu diperhalusi dan diberi penjelasan. Hal ini adalah kerana bagi merungkaikan kepentingannya dalam institusi agama Kristian, sekaligus dapat memberi kefahaman serta maklumat tambahan kepada penganut agama yang lain tentang salib dari kaca mata agama Kristian.

Salib iaitu cross dalam bahasa Inggeris atau crux dalam bahasa Latin adalah simbol yang terbentuk daripada pertembungan dua garisan bersilang pada pusatnya yang terdiri daripada empat arah lengan atau bahagian. ${ }^{1}$ Ia merupakan simbol yang tertua dan mempunyai pelbagai jenis atau bentuk. W. Berry dalam

1 Julien Ries, "Cross" dlm. Eliade, The Encyclopedia of Religion (New York: Macmillan Publishing Company, 1987), 155. 
Encyclopedia Heraldika sebagaimana yang disebut oleh Martigny (1974) dalam tulisannya bahawa tidak kurang daripada 385 jenis salib yang terdapat di dunia ini. Kebanyakan daripadanya tidak mempunyai sebarang kepentingan melainkan sebagai perhiasan seni dan lambang kepada ilmu persenjataan kuno.

Tinjauan dari konteks agama misalnya, jenis-jenis salib yang mempunyai hubungan dengan aspek ketuhanan atau keagamaan adalah; 'salib sama sisi' (equilateral cross) yang juga dipanggil 'salib Greek' (Greek cross), 'salib Latin' (Latin cross) dalam bahasa Latin dipanggil sebagai crux immissa atau capitata, 'salib bentuk-Tau' (Tau-shaped cross) dipanggil potencee atau commisa, 'salib ankh' (handle/ankh cross) dipanggil crux ansata, 'salib St. Andrew' yang juga dipanggil crux Decussata, 'salib gammate' (gammate cross), 'salib swastika' (swastika cross), 'salib maltese' (maltese Cross) ataupun 'salib berjalur' (rayed cross), 'salib lorraine' (lorraine cross) dengan dua atau tiga palang yang melintang dan 'salib perronee' (perronee cross) yang mempunyai palang pada kakinya. ${ }^{2}$

Pada beberapa zaman iaitu ketika pemerintahan Rom serta beberapa budaya masyarakat terdahulu telah menggunakan salib sebagai alat yang utama dalam menjalankan sesuatu hukuman terhadap pesalah laku undang-undang. ${ }^{3}$ Ia dianggap sebagai simbol kematian, penderitaan dan kehinaan. Walau bagaimanapun, selepas beberapa abad kematian Jesus Christ di tiang salib, persepsi terhadap makna simbol salib seakan berubah terutama di kalangan pengikut Jesus Christ iaitu penganut agama Kristian. Dalam merealisasikan kewajipan atau keinginan Tuhan dalam menebus dosa manusia di tiang salib, penyaliban Jesus Christ diertikan sebagai satu lambang penebusan dan pengorbanan. Rentetan daripada itu, akhirnya simbol salib menjadi lambang Jesus Christ itu sendiri dan lambang kepercayaan bagi penganut agama Kristian. ${ }^{4}$

2 J.A. Martigny, "Cross", dlm. James Hasting, Encyclopedia of Religion and Ethics (New York: Charles Scribner Son's, 1979), 324.

3 Laurice Diane Rogers, The Role of the Cross as a Transformative Symbol in Christian Counseling (Thesis Kedoktoran, The Southern Baptist Theological Seminary, 2005), 56.

4 Jacob E Safra, The New Encyclopedia Britanica (Chicago: Britanica, 2002), 753. 
Perkataan salib (cross) atau juga disebut sebagai crucify atau crucified memang tidak asing di dalam Bible. New Testament sememangnya dipenuhi dengan perkataan salib terutama dalam menceritakan mengenai peristiwa penyaliban dan kematian Jesus Christ di Golgotha. ${ }^{5}$ Malah terdapat pada bahagian tertentu di dalam teks, perkataan cross merujuk kepada kayu salib itu sendiri tanpa disandarkan kepada peristiwa tersebut. Ringkasnya, perkataan atau penceritaan mengenai salib di dalam New Testament adalah bersifat kepada persoalan sejarah dan teologi. Misalnya dari sudut sejarah, perkataan salib ditinjau sebagai instrumen atau alat yang melengkapi peristiwa penyaliban Jesus Christ. Manakala dari sudut teologi pula ia merujuk kepada aspek kepercayaan yang memandu penganut agar berpegang teguh kepada konsep penyelamatan yang melibatkan doktrin penyaliban serta penebusan dosa.

Buku The New International Dictionary of New Testament Theology (1975), merekodkan bahawa terdapat banyak ayat atau kenyataan mengenai salib di dalam Bible yang merujuk kepada konteks situasi atau keadaan sejarah terutama dalam peristiwa Jesus Christ disalib. ${ }^{6}$ Sebagai contoh dalam ayat Matthew 20: 19:

And will hand over to the Gentiles to be mocked and flogged and crucified. On the third day he will be raised to life. ${ }^{7}$

Manakala, antara ayat atau perkataan salib yang bersifat teologi (theological reflection) adalah berkenaan dengan suruhan Jesus agar memikul salib sepertinya atau dengan kata lain ia memberi makna supaya mempercayai kepada penyaliban Jesus Christ yang bertujuan untuk menghapuskan dosa manusia. ${ }^{8}$ Sebagaimana dalam ayat Matthew 16: 24 menyebut:

Then Jesus said to his disciple. 'Whoever wants to be my disciple must deny themselves and take up their cross and follow me. ${ }^{9}$

5 Colquhoun Frank, The Meaning of the Cross (London: The Tyndale Press, 1953), 9.

6 E. Brandenburger, "Cross", dlm. Colin Brown et. Al, The New International Dictionary of New Testament Theology (Michigan: Zondervan, 1975), 394395.

7 Bible, Matthew 20: 19.

8 Rahmat S.H., Dari Adam Sampai Muhammad Sebuah Kajian Mengenai Agama-Agama (Kelantan: Pustaka Aman Press Sdn. Bhd, 1984), 510.

9 Bible, Matthew 16: 24. 
Gambaran salib dengan makna teologi turut disebut di dalam surat-surat Paul (Pauline letters). 1 Corinthians 1: 18 merekodkan:

For the message of the of the cross is foolishness to those who are perishing, but to us who are being saved it is the power of God. ${ }^{10}$

Berbeza dengan Old Testament, perkataan salib sukar ditemui di dalam kitab ini kerana segala penceritaan mengenai Jesus Christ hanya tertakluk dalam New Testament semata. Namun begitu, bukanlah bermaksud perkataan salib tiada dalam kitab ini, tetapi ia digambarkan dengan perkataan yang lain. Sebagai contoh, perkataan wood, pole atau tree di dalam Old Testament merujuk kepada perkataan yang sama maksud dengan stake atau cross dalam New Testament iaitu sebagai alat hukuman mati atau penyeksaan. Walau bagaimanapun, tidak semua perkataan wood, pole atau tree di dalam Old Testament mahupun New Testament mengambarkan kepada makna itu. Kadang kala ia merujuk kepada makna literal perkataan itu sendiri sama ada sebagai kayu untuk membakar, alat untuk bahan binaan, tongkat atau menggambarkan pokok buah-buahan. Kesemuanya bergantung kepada konteks ayat tersebut. ${ }^{11}$

Justeru itu, bagi menjustifikasikan kewujudan salib dalam Old Testament, beberapa orang sarjana Kristian tradisional mentafsirkan sebahagian perkataan wood, pole atau tree adalah merujuk kepada makna yang sama dengan salib terutama dari konteks teologi. Kristian mempercayai bahawa salib Jesus Christ adalah satu-satunya simbol yang membawa kepada makna penyelamatan (salvation) dan ia bertepatan dengan sebahagian makna wood dalam Old Testament yang turut menggambarkan kepada makna tersebut. Contohnya, instrumen yang digunakan untuk membina bahtera Nabi Nuh, tangga Nabi Yaakob dan Tongkat Nabi Musa, sebagaimana yang telah disebut dalam Genesis 6: 14-16, 18: 1 dan Exodus 4: 2-5, 14: 16, 17: 5-6. Kesemua mukjizat ini diperbuat daripada kayu yang bertujuan untuk menyelamatkan manusia daripada bencana atau hukuman dari Tuhan. Dengan kata lain, menurut sarjana Kristian kayu salib yang digunakan dalam proses penebusan dosa oleh Jesus Christ di

10 Bible 1 Corinthians 1: 18.

11 B. Siede, "Cros", dlm., Colin Brown et al., The New International Dictionary of New Testament Theology (Michigan: Zondervan, 1975), 389-391. 
Golgota adalah kayu yang turut membawa kepada visi penyelamatan sama seperti mukjizat-mukjizat Nabi terdahulu. ${ }^{12}$

Umumnya perkataan salib (cross) atau penyaliban (crucifixion) masing-masing memiliki makna yang berbeza. Salib merujuk kepada simbol, alat atau instrumen yang digunakan semasa penyaliban Jesus Christ manakala perkataan penyaliban pula merujuk kepada peristiwa Jesus Christ disalib. Namun begitu, penelitian terhadap perbahasan tentang simbol salib dari perspektif teologi Kristian, mendapati bahawa sarjana-sarjana Kristian serta New Testament sendiri lebih kerap menggunakan istilah salib (cross) berbanding istilah penyaliban (crucifixion/crucified). Alasannya adalah kerana menurut sarjana Kristian salib adalah asas kepada peristiwa penyaliban Jesus Christ dan daripada penyaliban tersebut melahirkan teologi salib iaitu sebuah teologi tentang peranan Tuhan atau hikmah disebalik kematian-Nya di tiang salib. Oleh kerana itu, dalam kajian ini perkataan salib menjadi keutamaan dan digunakan dalam perbahasan tema-tema.

\section{Konsep Salib dari Konteks Teologi Kristian}

Salib dari perspektif agama Kristian memberi makna dan konsep yang cukup berbeza jika dibandingkan dengan tamadun, agama ataupun budaya yang lain. Peristiwa penyaliban Jesus Christ yang dipaparkan melalui kitab Bible menjadi tonggak utama pemuliaan terhadap salib yang pada asalnya hanyalah alat atau simbol biasa. Ayat-ayat bersifat teologikal yang termaktub dalam kitab Bible serta pandangan atau tafsiran tentang salib yang digagaskan oleh St. Paul seperti yang tercatat di dalam Epistle of Paul, menjadikan ia sebagai simbol yang mulia serta memiliki makna ketuhanan. Konsep-konsep tersebut adalah:

\section{1) Salib Sebagai Lambang Pengorbanan (Sacrifice)}

Old Testament dan New Testament telah memaparkan gambaran bahawa kematian Jesus Christ di kayu salib adalah sebagai lambang atau bukti kepada sifat pengorbanan. Agama Kristian mempercayai bahawa pengorbanan yang ditawarkan oleh Jesus Christ merupakan pengorbanan yang sangat efektif dan sempurna, jika dibandingkan dengan pengorbanan yang dilakukan oleh makhluk atau orang lain. Dalam merealisasi misi penyelamatan

12 Ries, The Encyclopedia of Religion, 164. 
Tuhan untuk memulihkan kembali hubungan-Nya dengan manusia setelah dibelenggu dosa warisan, Jesus Christ diutuskan untuk menjadi perantara atau orang tengah dan bertanggungjawab untuk korban di tiang salib demi mencapai misi tersebut. Lantaran daripada itu, Kristian menganggap ia sebagai satu pengorbanan yang sebenar serta bersifat kekal kerana dilakukan semata-mata untuk pemulihan dan penyatuan dengan Tuhan. ${ }^{13}$

Selain itu, hujah yang lain adalah perumpamaan Jesus Christ sebagai kambing (lamb) di dalam New Testament iaitu pada ayat John 1: 29 \& 36 mempunyai hubungan yang rapat dengan makna pengorbanan. Pada zaman Old Testament, Tuhan telah memerintahkan hamba-Nya supaya berkorban dengan melepaskan sesuatu yang penting berupa haiwan seperti kambing untuk dipersembah atau dikorbankan. Aktiviti ini disyariatkan bagi melahirkan sifat pengorbanan manusia kepada Tuhan, di samping dapat menebus dosa-dosa kesalahan manusia. Walau bagaimanapun, perintah tersebut berubah apabila Tuhan menurunkan New Testament. Dalam kitab ini, Tuhan berkehendak sendiri untuk menebus dosa manusia melalui pengorbanan yang dilakukan oleh Jesus Christ iaitu mati di tiang salib. Jesus Christ seolah-olah bertindak sebagai kambing korban seperti yang dinyatakan di dalam Old Testament sekaligus menyifatkan ia sebagai penebus dosa yang memiliki sifat pengorbanan dan kasih sayang yang tinggi kerana sanggup mati demi hamba-Nya. Justeru itu, definisi salib sebagai lambang pengorbanan dalam agama Kristian adalah manifestasi daripada gambaran atau peristiwa tersebut. ${ }^{14}$

\section{2) Salib Sebagai Lambang Kejayaan/Kemenangan (Victory)}

New Testament dan para ahli gereja awal telah mempersembahkan salib sebagai lambang kemenangan atau kejayaan Jesus Christ dalam mengatasi dosa, kematian dan syaitan. Makna ini menjadi tonggak utama kepada amalan peribadatan dalam sambutan hari Paskah (Easter), di samping menjadi pegangan serta kefahaman masyarakat Kristian bagi mengatasi segala kejahatan dan

13 Alister E. McGrath, Christian Theology an Introduction (London: Wiley Blackwell Publication, 2011), 320.

14 M. Ag. Tarpin, "Pandangan Kristen Tentang Dosa: Asal Muasa dan Cara Menbusnya," Jurnal Usuluddin 229 (2010): 221-233. 
penindasan. ${ }^{15}$ Sejarah agama Kristian menunjukkan bahawa kepercayaan terhadap Jesus Christ sebagai pembawa kejayaan begitu masyhur semasa abad pertengahan. Pada abad ini pengaruh sihir, mitos dan amalan khurafat begitu ketara diamalkan oleh masyarakat Barat. Sebagai pelindung kepada ancaman dan kejahatan amalan tersebut, masyarakat mempercayai bahawa kejayaan yang dibawa oleh Jesus Christ melalui salibnya mampu untuk membantu, menyembuh, melindungi dan menyelamatkan mereka. Oleh sebab itu, masyarakat menjadikan salib sebagai tangkal serta azimat, sama ada dengan cara memakainya pada badan atau diletakkan di dalam bilik, rumah, kedai dan sebagainya. $^{16}$

Namun begitu, menurut sarjana Kristian kejayaan Jesus Christ yang paling ketara dalam bayangan salib adalah pembebasan manusia dari belenggu dosa warisan. Kesalahan yang dilakukan oleh Adam dan Eve di syurga kerana melanggar perintah Tuhan mengakibatkan generasi manusia terpaksa menanggung kesan daripada dosa tersebut. Impak dari dosa ini menyebabkan fizikal dan spiritual menjadi mati, secara tidak langsung menjauhkan manusia daripada Tuhan. Bertitik tolak daripada keadaan tersebut, manusia memerlukan kehidupan baru untuk menjalinkan hubungan suci dengan Tuhan. Oleh kerana itu, Tuhan telah mengutus anaknya iaitu Jesus Christ bagi menebus dosa tersebut melalui jalan penyaliban dan penyelamatan. Kebangkitan semula Jesus Christ pada hari ketiga setelah disalib membawa maksud bahawa manusia telah bebas daripada belenggu dosa warisan dan menuju ke arah kehidupan yang lebih baik di sisi Tuhan. Justeru itu, peristiwa ini dianggap sebagai kejayaan atau kemenangan yang besar dalam agama Kristian, sekaligus mempengaruhi konsep simbol salib itu sendiri. ${ }^{17}$

15 Alister E. McGrath, Christian Theology an Introduction, 322.

16 Markus Hildebrandt Rambe, "Penuntun Simbol-Simbol Ibadah Kristen Sebuah Ensiklopedi Dasar," Jurnal STT Intim Makassar 23 (2004)1: 19-42.

17 Khadijah Binti Hambali, "Konsep Salvation Menurut Agama Kristian: Satu Huraian Awal," Jurnal Usuluddin 46 (1999): 10: 43-50. 


\section{3) Salib Sebagai Lambang Kasih Sayang Tuhan (Demonstra- tion of God's Love)}

Makna atau konsep lain di sebalik simbol salib adalah penonjolan sifat kasih sayang Tuhan kepada manusia. Rancangan Tuhan untuk mati di tiang salib demi menebus dosa manusia adalah semata-mata untuk memaparkan sifat kasih sayangnya. Para ahli teologi Kristian menyifatkan bahawa kasih sayang yang ditunjukkan oleh Tuhan adalah amat besar dan mulia kerana Tuhan terpaksa melalui pelbagai penderitaan dan penghinaan yang membawa kepada kematian demi membebaskan manusia daripada perhambaan dosa. Pengorbanan ini membuktikan bahawa Tuhan sangat komited untuk membantu manusia sekaligus menjadi teladan kepada penganut agama Kristian. Selain itu juga, kasih sayang Tuhan yang dipromosikan melalui jalan salib umpama jambatan untuk mengeratkan kembali hubungan Tuhan dengan manusia. Manusia seolah-olah telah dibawa masuk oleh Tuhan ke dalam dunia baru yang lebih baik daripada sebelumnya. Justeru itu, kenyataan ini menjadi hujah yang kuat bagi menjustifikasikan salib sebagai lambang kasih sayang Tuhan. ${ }^{18}$

Mesej atau konsep tersebut turut menjadi tema utama dalam neraca peribadatan dan kerohanian agama Kristian. Para ahli teologi Kristian mengatakan bahawa penghayatan melalui penderitaan Jesus Christ di tiang salib membantu penganut untuk menjadi lebih taat dan merasai pengalaman beragama. Penghayatan tersebut memberi pengaruh kepada salib yang dilihat sebagai alat yang menjadi saksi kepada penderitaan dan kematian Jesus Christ dalam menjayakan misinya sebagai penyelamat. Kristian mempercayai bahawa adalah sukar bagi Tuhan untuk menjadi korban semata-mata demi manusia. Namun begitu, kerana sifat kasih sayangnya yang tinggi kepada manusia, Tuhan secara sukarela malah sanggup untuk mati bagi menebus dosa-dosa tersebut. Ini membuktikan bahawa kasih sayang yang ditunjukkan oleh Jesus Christ adalah melampaui segalanya di dunia ini, secara tidak langsung mengklasifikasikan ia sebagai Tuhan yang maha penyayang di sisi agama Kristian. ${ }^{19}$

${ }^{18}$ Laurice Diane Rogers, The Role of Cross as a Transformative Symbol in Christian Counseling, 67.

19 Alister E. McGrath, Christian Theology an Introduction, 332. 


\section{4) Salib Sebagai Lambang Pendamaian (Reconciliation)}

Merujuk kepada surat-surat Paul (Epistle of Paul), perkataan pendamaian atau reconciliation adalah istilah teologi yang sangat jelas dinyatakan dalam New Testament. Ia dapat dilihat berdasarkan kepada ayat-ayat yang tercatat dalam 2 Corinthians 5: 16-21 dan Colossians 1: 19-23. Menerusi ayat-ayat ini, St. Paul merupakan ahli teologi Kristian yang pertama dengan jelas menyebut bahawa kematian Jesus Christ di tiang salib adalah sebagai lambang kepada pendamaian. Pendamaian tersebut merujuk kepada satu fenomena untuk mewujudkan kembali atau membina semula hubungan yang telah rapuh di antara Tuhan dengan manusia. Agama Kristian mengakui bahawa manusia tidak mampu untuk mendamaikan dirinya dengan Tuhan kerana manusia hidup di bawah pengaruh syaitan. Oleh kerana itu, manusia memerlukan wakil Tuhan iaitu Jesus Christ sebagai agen kepada proses pendamaian itu. ${ }^{20}$

Tambahan itu, ada yang berpandangan bahawa pendamaian tersebut merujuk kepada situasi atau keadaan untuk mendamaikan serta menyatupadukan di antara orang Yahudi dengan bukan Yahudi. Ia bertujuan untuk memansuhkan segala undang-undang Yahudi dan di ganti dengan undang-undang baru iaitu agama Kristian. ${ }^{21}$ Selain itu, berdasarkan kepada surat-surat Paul juga, ahli-ahli teologi Kristian berikutnya mengatakan bahawa pendamaian yang dibawa oleh Tuhan melalui Jesus Christ adalah meliputi semua perkara yang ada di dunia ini. Bukan sahaja ia mendamaikan hubungan antara Tuhan dengan manusia, namun lebih daripada itu, proses tersebut turut mendamaikan seluruh alam semesta. Oleh yang demikian, berdasarkan penjelasan tersebut sarjana Kristian menilai salib sebagai lambang pendamaian. Seperti konsep-konsep salib yang lain dalam aspek peribadatan dan kepercayaan, salib sebagai lambang pendamaian turut melahirkan kesedaran spiritual serta penghayatan yang tinggi terhadap nilai-nilai agama khususnya bagi penganut agama Kristian. ${ }^{22}$

20 Joy L. Ames, Paul's Theology of the Cross as Foolishness and Reconciliation (Disertasi, School of Theology and Missions Oral Roberts University, 2010), 45.

21 J.C. Lambert, "Cross," dlm. James Hasting, Dictionary of the Bible (NewYork: Charles Scribner Son's, 1963), 192.

22 Ames, Paul's Theology of the Cross, 62. 


\section{5) Salib Sebagai Lambang Penyelamatan (Salvation)}

Konsep salib sebagai lambang penyelamatan merupakan konsep teologi yang sangat dominan dan terkenal dalam agama Kristian. Ini kerana konsep penyelamatan merupakan doktrin utama dalam agama Kristian dan merupakan salah satu daripada rancangan Tuhan untuk bersatu, menebus dosa dan membantu manusia. ${ }^{23}$ Istilah penyelamatan sering kali dikaitkan dengan matlamat utama masyarakat Kristian untuk terus kekal berada dalam ajaran Jesus Christ dan hidup dalam kemuliaan naungan Tuhan. Ahli teologi Kristian meletakkan istilah penyelamatan sebagai satu tujuan atau misi untuk menyelamatkan kehidupan individu Kristian khususnya selepas kematian daripada tanggungan segala dosa dan hukuman di atas dosa tersebut. Untuk mencapai dan menyempurnakan misi penyelamatan, Jesus Christ telah terpilih sebagai penyelamat serta penebus dosa melalui jalan penyaliban iaitu mati di tiang salib. ${ }^{24}$

Penelitian dari sudut ilmu soteriology dan christology mendapati bahawa perbahasan mengenai doktrin penyelamatan Tuhan serta personaliti Jesus Christ sering kali dikaitkan dengan salib. Oleh kerana itu, dalam agama Kristian salib menjadi asas kepada doktrin penyelamatan Tuhan. ${ }^{25}$ Dengan berpandukan kepada ayat-ayat dalam New Testament, misalnya pada ayat Matthew 1: 21, Galathians 3:13, Colossians 2: 14 dan Roman 6: 14, ahli teologi Kristian mengesahkan atau mentafsirkan bahawa salib merupakan pelengkap kepada aktiviti penebusan dosa dan merupakan instrumen yang penting dalam menyempurnakan proses penyelamatan. Mereka juga menganggap bahawa salib merupakan sebahagian daripada wahyu serta termasuk dalam perancangan Tuhan bagi menjayakan misinya. Berdasarkan penjelasan ini, maka agama Kristian mendefinisikan salib sebagai lambang penyelamatan Tuhan. ${ }^{26}$

23 Thomas Ulun Ismoyo, "Penderitaan Sebagai Penyelamatan Studi Komparasi Antara Penderitaan Yesus Kristus Dengan Penderitaan Iman Husayn," Jurnal Teologi 42 (2012)1: 39-50.

24 Khadijah Binti Hambali, "Konsep Salvation Menurut Agama Kristian: Satu Huraian Awal," 44.

25 Alister E. McGrath, Christian Theology an Introduction, 319.

${ }^{26}$ Christopher Stoner Carter, A Theology of the Cross as a Guide for Spiritual Formation (Disertasi, Asbury Theological Seminary, 2005), 12. 


\section{Teologi Salib St. Paul}

Teologi salib (Theology of The Cross) adalah cara untuk memahami, beramal serta merasai kehadiran Tuhan dalam kehidupan seharian penganut agama Kristian melalui nilai-nilai yang terdapat pada salib. ${ }^{27}$ Nilai-nilai itu merujuk kepada makna yang tersirat di sebalik peristiwa penyaliban Jesus Christ yang mencakupi konsep-konsep salib sebagaimana yang telah diperjelaskan iaitu sebagai lambang pengorbanan, kejayaan, kasih sayang dari Tuhan, pendamaian dan penyelamatan. Konsepkonsep ini menjadi pemangkin kepada keteguhan nilai ketuhanan dalam diri penganut agama Kristian, secara tidak langsung melahirkan sifat ketaatan kepada Tuhan dan menjadi panduan dalam pembentukan kerohanian atau spritual. Ahli teologi pertama dan terawal yang membentuk serta membahaskan berkenaan dengan teologi salib adalah St. Paul (3M-67M). St. Paul merupakan pengasas kedua bagi agama Kristian.

Terdapat beberapa aspek penting yang menjadi keutamaan dalam pembentukan doktrin-doktrin agama Kristian oleh St. Paul. Selain teks-teks Bible, gagasan teologi beliau iaitu teologi salib turut menjadi asas yang menguatkan doktrin-doktrin agama Kristian. Sekiranya diteliti pada keseluruhan penulisan Paul, salib menjadi tema atau fokus utama bagi menterjemahkan gaya hidup beragama masyarakat Kristian yang sebenar. Menurut Paul, makna di sebalik penyaliban Jesus Christ atau lebih sinonimnya di sebut sebagai salib merupakan pusat serta tulang belakang kepada seluruh aktiviti Jesus Christ semasa hayat, mati dan kebangkitannya. Lebih dari itu Paul turut mendakwa bahawa salib diumpamakan sebagai pantulan daripada kitab Gospel itu sendiri dan pelengkap kepada seluruh doktrin yang terdapat dalam agama Kristian. ${ }^{28}$ Penerimaan terhadap Jesus Christ sebagai Tuhan yang membawa kepada penyelamatan bererti seseorang individu tersebut telah memilih jalan salib atau dengan kata lain mereka turut disalib bersama-sama Jesus Christ. Dalam hal ini, Paul tidak teragak-agak untuk menyatakan bahawa dirinya juga disalib

27 Carter, Christopher Stoner, A Theology of the Cross as a Guide for Spiritual Formation, 13.

28 J.C. Lambert, Dictionary of the Bible, 192. 
bersama Jesus Christ, sekaligus mengangkat beliau sebagai nabi atau wakil Tuhan dalam menyebarkan agama Kristian. ${ }^{29}$

Oleh kerana itu, salib atau teologi salib menjadi mesej utama bagi Paul dalam dunia misionarinya. Surat-surat Paul berserta catatan sejarah menunjukkan bahawa teologi salib seakan tulang belakang dalam misinya untuk mengembangkan ajaran Kristian. Paul memfokuskan seluruh aspek ketuhanan dan spiritual Kristian ke dalam kesatuan salib yang bertujuan untuk mengarahkan diri kepada pengabdian terhadap Jesus Christ. Sebagaimana yang tercatat di dalam ayat 1 Corinthians 1: 17-25 dan Galatians 2: 1920, jelas menggambarkan bahawa misi dakwah Paul terhadap gereja Corinthians serta Galatians, bukan sahaja untuk menjelaskan mesej Kristian acuan daripada dirinya sendiri, namun beliau berusaha untuk menyatupadukan gereja-gereja tersebut di bawah naungan salib iaitu menjadikan salib sebagai model dalam pembentukan kerohanian, peribadatan dan kehidupan seharian. Natijahnya, simbol salib menjadi cerminan kepada penganut agama Kristian terutama dalam memantapkan jati diri dan menguatkan keimanan terhadap Jesus Christ. ${ }^{30}$

\section{Teologi Salib Martin Luther}

Martin Luther (1483M-1546M) adalah salah seorang tokoh reformis agama Kristian yang terkenal di Jerman pada abad 16 Masihi. Beliau merupakan anak kepada sepasang suami isteri Hans Luther dan Margarette. Meskipun hidup di dalam lingkungan keluarga yang miskin, namun beliau berjaya menghabiskan pelajarannya sehingga ke peringkat universiti dalam bidang undang-undang. Oleh kerana minatnya yang mendalam terhadap agama, beliau turut mempelajari ilmu falsafah, teologi, bahasa dan ilmu-ilmu yang berkaitan dengan agama Kristian. Pencapaiannya yang baik dalam akademik diakui oleh orang ramai serta gereja Katolik, malah pihak universiti Wittenberg tertarik pada Martin Luther sekaligus melantik beliau sebagai profesor dalam bidang ilmu falsafah. ${ }^{31}$

29 Laurice Diane, Rogers, The Role of Cross as a Transformative Symbol in Christian Counseling, 28.

${ }^{30}$ Laurice Diane Rogers, The Role of Cross as a Transformative Symbol in Christian Counseling, 30-33.

31 Rahmat S.H. Dari Adam Sampai Muhammad, 468. 
Teologi salib Martin Luther merupakan adaptasi daripada teologi salib St. Paul. Tujuan ia diutarakan pada ketika itu adalah untuk menentang sebahagian pandangan para teologi awal tentang teologi kemuliaan (Theology of Glory) yang dilihat tidak memberi kebaikan malah menjauhkan penganut Kristian daripada nilai-nilai pengorbanan dan ketuhanan Jesus Christ. Teologi kemuliaan menuntut penganut agar menjiwai atau menggambarkan tabii serta sifat Tuhan berdasarkan kepada seluruh ciptaan-Nya. Menurut Martin Luther pendekatan teologi kemuliaan ini seolah-olah mengatur tindak tanduk Tuhan melalui logik akal dan membiarkan manusia menentukan perbuatan Tuhan. Baginya, hal ini menyebabkan manusia menjadi kurang bijaksana serta tidak mampu mengubah hati individu ke arah yang lebih baik. Oleh sebab itu, Martin Luther menekankan kepentingan terhadap teologi salib sebagai medium utama bagi melahirkan individu yang mulia serta taat kepada Tuhan, khususnya melalui penghayatan terhadap penderitaan dan pengorbanan Jesus Christ di tiang salib. ${ }^{32}$

Selain itu, motif utama Martin Luther menekankan secara tegas penghayatan terhadap teologi salib adalah untuk menyedarkan pihak gereja daripada amalan-amalan yang bercanggah dengan asas ajaran Kristian seperti yang telah diajarkan oleh Jesus Christ. Inspirasi daripada teologi salib yang tercatat di dalam surat-surat Paul menjadi pemangkin buat Martin Luther dalam gerakannya. Martin Luther menyerang segelintir penguasa gereja dan ahli teologi yang melakukan ketidakadilan dalam pentadbiran serta mengaut keuntungan daripada hasil jualan surat pengampunan dosa. Menurutnya, tindakan tersebut menjauhkan manusia daripada merasai penderitaan serta kesengsaraan Jesus Christ di tiang salib. Beliau beranggapan bahawa sepatutnya gereja mengutamakan atau mempromosikan penderitaan Jesus Christ daripada menjual surat pengampunan dosa yang palsu bagi memperolehi keampunan daripada Tuhan. Peristiwa ini membuatkan Martin Luther terpisah daripada gereja Katolik, sekaligus melahirkan mazhab baru dalam agama Kristian. ${ }^{33}$

\footnotetext{
32 Mariani Febriana, "Teologi Salib Martin Luther dan Implikasinya dalam Dunia Masa Kini,” JTA 44-45, (2010)12: 36-54.

33 Mariani, "Teologi Salib Martin Luther," 49-52.
} 


\section{Hubungan Salib dengan Doktrin Penebusan Dosa Serta Penyelamatan.}

Dalam Agama Kristian salib atau peristiwa penyaliban di anggap sebagai satu-satunya kunci yang menyempurnakan asas agama iaitu pelengkap kepada aktiviti penebusan dosa serta penyelamatan. Ia juga diakui sebagai hati atau ibu kepada gospel dan pusat utama bagi kepercayaan serta pegangan penganut agama Kristian. Sarjana Kristian mendakwa bahawa salib seolah-olah membayangi seluruh tema-tema yang terkandung di dalam New Testament, malah lebih dari itu mereka menganggap bahawa New Testament diwahyukan adalah untuk memahamkan manusia mengenai jalan salib atau lebih tepat makna yang tersirat di sebalik peristiwa kematian Jesus Christ di tiang salib. ${ }^{34}$

Salib mempunyai kaitan serta hubungan yang rapat dengan pembentukan doktrin penebusan dosa serta melengkapi doktrin penyelamatan. Bagi merungkai hubungan di antara salib dengan kedua doktrin tersebut dengan lebih terperinci, penelitian terhadap New Testament dan pandangan sarjana Kristian perlu diberi keutamaan. Ini kerana, agama Kristian mengiktiraf serta mengakui bahawa kewujudan salib adalah berasal atau bersumberkan daripada kitab tersebut. Oleh itu, tumpuan terhadap salib akan dibincangkan berdasarkan kepada dua aspek utama iaitu peristiwa penyaliban Jesus Christ di Golgota dan berikutnya adalah pandangan sarjana Kristian mengenai konsep salib dari perspektif teologi.

Peristiwa mengenai penyaliban Jesus Christ banyak dinukilkan dalam Gospel New Testament. Sebagai contoh pada ayat Matthew 27: 32-50, Mark 15: 20-37, Luke 23: 26-46 dan John 19: 17-34. Salah satu ayat tersebut iaitu Matthew 27: 32-50 ada merekodkan:

As they were going out, they met a man from Cyrene, named Simon, and they forced him to carry the cross. They came to a place called Golgotha (Which means; the place of the skull'). There they offered Jesus wine to drink, mixed with gall; but after tasting it, he refused to drink it. When they had crucified him, they divided up his clothes by casting lots. And sitting down, they kept watch over him there. Above his head they placed the written charge against him: this is Jesus, the

${ }^{34}$ Colquhoun Frank, The Meaning of the Cross, 7-9. 
king of the Jews. Two rebels were crucified with him, one on his right and one on his left. Those who passed by hurled insult at him, shaking their heads and saying, 'You who are going to destroy the temple and build it in three days, save yourself! Come down from the cross, if you are the Son of God!. In the same way the chief priests, the teachers of the law and the elders mocked him. 'He saved others, they said, but he can't save himself! He's the king of Israel! Let him come down now from the cross, and we will believe in him. He trusts in God. Let God rescue him now ifhe wants him, for he said, 'I am the Son of God'. In the same way the rebels who were crucified with him also heaped insults on him. From noon until three in the afternoon darkness came over all the land. About three in the afternoon Jesus cried out in a loud voice, 'Eli Eli, lema sabachthani?' (which mean 'My God, my God, why have you forsaken me?'). When some of those standing there heard this, they said, 'He's calling Elijah'. Immediately one of them ran and got sponge. He filled it with wine vinegar, put in on a staff, and offered it to Jesus to drink. The rest said, 'Now leave him alone. Let's see if Elijah comes to save him'. And when Jesus had cried out again in a loud of voice, he gave up his spirit. ${ }^{35}$

Ayat di atas merupakan plot penceritaan kematian Jesus Christ di atas tiang salib dalam Gospel. Secara literalnya, ayat tersebut menunjukkan bahawa kematian Jesus Christ adalah disebabkan oleh hukuman daripada pemerintah atau kebencian masyarakat Yahudi kepada beliau yang di anggap sebagai perosak, perampas kuasa dan menyeleweng daripada ajaran Yahudi. Mereka memperolok-olokkan Jesus Christ serta melemparkan kata-kata kesat kepadanya. Namun begitu, menurut kefahaman sarjana Kristian peristiwa penyaliban tersebut bukanlah satu acara hukuman nyata yang bersifat duniawi ke atas Jesus Christ sebagai pesalah laku atau pelanggar undang-undang Yahudi. Akan tetapi ia adalah salah satu langkah pertama atau satu rancangan Tuhan yang berkeinginan untuk menjadi pengantara bagi menghapuskan dosa manusia melalui kematiannya di tiang salib. Tambah mereka

35 Bible, Matthew 27: 32-50 
lagi, sekiranya Jesus Christ tidak mati di tiang salib maka tidak akan ada konsep penebusan dosa. ${ }^{36}$

Oleh yang demikian, penyaliban Jesus Christ di angkat menjadi peristiwa yang terpenting dan sebagai salah satu pokok kepercayaan atau doktrin utama dalam agama Kristian. seseorang itu tidak dianggap sebagai penganut agama Kristian sekiranya tidak mempercayai atau mengakui penyaliban Jesus Christ. Dalam agama Kristian penyaliban Jesus Christ seolah-olah suatu jalan nasib yang tidak boleh tidak mesti ditempuh oleh Jesus Christ. Tuhan telah mengutus anaknya ke dunia ini untuk dikorbankan bagi menebus dosa manusia. Kristian mempercayai bahawa semasa kehidupannya di dunia, Jesus Christ sendiri telah memberitakan kesengsaraan yang akan ditempuhnya di saat akhir hayatnya. Matthew 16: 21-22 ada merekodkan. ${ }^{37}$

From that time on Jesus began to explain to his disciple that he must go to Jerusalem and suffer many things at the hands of the elders, the chief priests and the teachers of the law, and that he must be killed and on the third day be raised to life. Peter took him aside and began to rebuke him. 'Never, Lord!' he said. 'This shall never happen to you!'. 38

Kepercayaan terhadap penyaliban Jesus Christ diperkukuhkan lagi dengan pandangan teologi sarjana Kristian terhadap beberapa potongan ayat Bible yang merujuk kepada salib sebagai jalan yang terbaik untuk memandu diri individu ke arah spiritual yang lebih baik. Sebagai contoh ayat Matthew 16: 24 ada menyebut:

Then Jesus said to his disciple, 'Whoever wants to be my disciple must deny themselves and take up their cross and follow me. ${ }^{39}$

Semasa pemerintahan Rom, salib difahami sebagai alat penyeksaan yang membawa kepada penghinaan dan kematian. Namun begitu dalam konteks agama Kristian salib ditafsirkan sebagai spiritual application iaitu sesuatu yang mampu menggerakkan atau dapat memberi kesan kepada spiritual

\footnotetext{
36 Arsyad Thalib Lubis, Perbandingan Agama Kristen dan Islam (Kuala Lumpur: Pustaka Melayu Baru, 1982), 143.

37 Rahmat S.H., Dari Adam Sampai Muhammad Sebuah Kajian Mengenai Agama-agama, 510.

38 Bible, Matthew 27: 32-50

39 Bible, Matthew 16: 24
} 
Kristian. Ayat 'take up their cross and follow me' di atas merujuk kepada tingkah laku atau sikap Jesus Christ yang perlu diikuti serta dicontohi oleh individu seperti suci, bersederhana, rendah diri, tenang, lemah lembut dan sentiasa ceria. ${ }^{40}$

Tujuan utama penebusan dosa oleh Jesus Christ adalah untuk menyelamatkan manusia. Untuk itu, kematian di atas salib atau dengan kata lain di sebut sebagai mati di jalan salib merupakan cara yang paling efektif dan terpilih untuk merealisasikan tujuan suci tersebut. Menurut agama Kristian kematian Jesus Christ di atas tiang salib adalah satu pengorbanan terbesar yang dilakukan oleh Tuhan dan secara tidak langsung memperlihatkan bahawa betapa kasihnya Jesus Christ kepada manusia. Kesan daripada itu, salib sangat dimuliakan dan menjadi manifestasi atau rujukan bagi seluruh kehidupan beragama penganut Kristian. New Testament Letters atau dikenali sebagai Pauline Letters banyak menekankan mengenai salib atau teologi salib sebagai penggerak kepada spiritual serta mesej yang bertindak bagi menyatukan komuniti dan ahli gereja. Sebagai contoh pada ayat 1 Corintians 1: 18-25, Galatians 2: 19-21, Galatians 6: 14 dan Philippians 2: 5-11.

Kebanyakan ayat yang terdapat di dalam New Testament Letters adalah surat-surat St. Paul yang berunsurkan seruan, teologi, kata-kata nasihat dan cara atau tingkah laku beragama yang sepatutnya dianuti oleh agama Kristian. Sebahagian besar doktrin-doktrin agama Kristian difahami dan terbentuk berdasarkan kepada ayat-ayat yang terdapat pada bahagian tersebut. Berkenaan dengan salib atau teologi salib, St Paul merumuskan bahawa salib adalah asas untuk membina hubungan dengan Tuhan dan sumber utama untuk mengenali ajaran Kristian. Menurutnya, salib merupakan pantulan daripada Gospel itu sendiri dan menjadi identitinya bagi menyebarkan agama Kristian serta mentransformasikan ajaran gereja. Tambahan daripada itu, salib juga dianggap sebagai simbol yang membentuk kesatuan masyarakat, komuniti, individu mahupun kumpulan tertentu dan dijadikan sebagai asas kepada peribadatan dan aktiviti keagamaan. $^{41}$

${ }^{40}$ Christopher Stoner Carter, A Theology of the Cross as a Guide for Spiritual Formation, 22.

41 Rogers, Laurice Diane, The Role of Cross as a Transformative Symbol in Christian Counseling, 31-34. 
Justeru itu, berdasarkan kenyataan di atas jelas menunjukkan bahawa salib mempunyai kaitan serta hubungan yang rapat dengan doktrin penebusan dosa serta penyelamatan. Tanpa kepercayaan terhadap salib atau kematian Jesus Christ di atas tiang salib, maka tidak akan wujud doktrin penebusan dosa serta penyelamatan dalam agama Kristian. Ringkasnya, kepercayaan terhadap kematian Jesus Christ di atas tiang salib sebagai salah satu daripada rancangan Tuhan, kemudian diperkukuhkan lagi dengan hujah-hujah St. Paul dalam New Testament Letters Letters seperti Corinthians, Galatians dan Philippians secara tidak langsung membuatkan agama Kristian mengakui bahawa salib adalah pelengkap bagi kedua doktrin tersebut dan menjadi simbol yang terpenting dalam kehidupan masyarakat Kristian. ${ }^{42}$

\section{Salib dan Pengalaman Psikologi}

Sekiranya diteliti, perbahasan mengenai salib lebih banyak menjurus ke arah spiritual serta teologi. Ia dapat dilihat berdasarkan kepada konsep atau makna yang tersirat di sebalik simbol salib itu sendiri, penjelasan daripada kitab Bible dan matlamat utama kematian Jesus Christ di atas tiang salib iaitu bagi menyempurnakan doktrin penebusan dosa serta melengkapkan doktrin penyelamatan. Kesemua penjelasan tersebut adalah bersifat dalaman yang mana bertujuan untuk menggerakkan spiritual individu dan secara tidak langsung bertindak sebagai penguat kepada teologi atau doktrin-doktrin yang terdapat dalam agama Kristian.

Namun begitu dari sudut yang lain pula, salib turut memberi kesan kepada masyarakat Kristian terutama dalam aspek psikologi. Secara umumnya, ahli psikologi berpandangan bahawa sesuatu simbol itu dapat menyentuh serta menggerakkan manusia secara mendalam dan holistik, bukan saja dimensi intelektual ia juga dapat berinteraksi dengan dimensi emosi, spiritual dan jasmani. ${ }^{43}$ Ada pula yang berpendapat bahawa sistem simbol juga dapat memberi kesan kepada jiwa manusia dengan membuka saluran

42 Arsyad Thalib Lubis, Perbandingan Agama Kristen dan Islam, 143.

43 Markus Hildebrandt Rambe, "Penuntun Simbol-simbol Ibadah Kristen Sebuah Ensiklopedi Dasar," 21. 
intuisi serta menjadi platform atau alat untuk berkomunikasi pada keadaan-keadaan tertentu. ${ }^{44}$

Oleh yang demikian, masyarakat Kristian mengakui bahawa simbol salib memiliki ciri-ciri tersebut. Dalam agama Kristian salib merupakan simbol agama yang mulia atau superior yang memiliki pelbagai fungsi. Dari aspek psikologi, makna yang tersirat di sebalik simbol salib dijadikan sebagai rujukan serta sumber bagi para kaunseling Kristian dalam menjalankan proses pemulihan minda, motivasi dan terapi psikologi terhadap pesakit mental atau jiwa. Modul kaunseling dikaitkan dengan pengalaman-pengalaman keagamaan yang berpusat kepada salib membantu pesakit dalam menghadapi serangan mental, gangguan emosi, masalah moral dan sekaligus meningkatkan keyakinan serta semangat diri. Melalui salib juga, ahli kaunseling telah mencipta suasana pembangunan kendiri yang menggalakkan. Sebagai contoh mengingatkan pesakit tentang pembinaan hubungan yang baik dengan Tuhan melalui salib, pengorbanan Jesus Christ di atas tiang salib, kurniaan kasih sayang Tuhan kepada manusia, hikmah pengampunan dosa dan sebagainya. ${ }^{45}$

\section{Penutup}

Dapat disimpulkan bahawa simbol salib merupakan simbol yang penting dan signifikan dalam tradisi agama Kristian. Ia diakui dan disahkan oleh Bible merangkumi ayat-ayat yang terkandung di dalam Old Testament serta New Testament. Fokus utama Salib dalam agama Kristian bukan saja merujuk sebagai simbol pengenalan bagi gereja atau agama Kristian semata, akan tetapi lebih dari itu salib ditunjangi oleh makna-makna teologi yang menjadi pegangan serta kepercayaan bagi masyarakat Kristian iaitu salib sebagai lambang pengorbanan, kejayaan, kasih sayang daripada Tuhan, pendamaian dan penyelamatan.

Sejak dari dahulu perbahasan mengenai salib sering kali menjadi keutamaan dalam dunia teologi Kristian seperti dalam teori teologi salib oleh St. Paul yang merupakan pengasas kedua bagi agama Kristian. Kemudian perincian mengenai simbol salib

44 Hendro Prabowo \& Nosan Feri, "Simbol salam Psikoterapi Transpersonal," PESAT 53 (2009)3: 52-57.

45 Rogers, Laurice Diane, The Role of Cross as a Transformative Symbol in Christian Counseling, 206-222. 
dikembangkan lagi dengan pandangan daripada Martin Luther. Menerusi penelitian terhadap Bible iaitu New Testament dan pandangan daripada sarjana Kristian, simbol salib dilihat sebagai instrumen yang dapat menghubungkan di antara tuhan dengan manusia terutama dalam doktrin penebusan dosa serta penyelamatan. Salib umpama tulang belakang bagi kedua-dua doktrin tersebut. Ini menunjukkan bahawa tanpa simbol salib serta penyaliban Jesus Christ di tiang salib maka doktrin penebusan dosa dan penyelamatan sukar untuk diketahui atau difahami.

\section{Rujukan}

Ames, Joy L. Paul's Theology of the Cross as Foolishness and Reconciliation. Disertasi, School of Theology and Missions Oral Roberts University, 2010.

Benson, George Willard. The Cross its History \& Symbolism. New York: Hacker Art Book, 1976.

Brandenburger, E. "Cross." Dlm. Brown, Colin, Coenan, Lothar, Beyreuther \& Erich. The New International Dictionary of New Testament Theology. Michigan: Zondervan, 1975.

Carter, Christopher Stoner. A Theology of the Cross As A Guide For Spiritual Formation. Thesis Kedoktoran, Asbury Theological Seminary, 2005.

Frank, Colquhoun. The Meaning of the Cross. London: the Tyndale Press, 1953.

Hendro Prabowo \& Nosan Feri. "Simbol dalam Psikoterapi Transpersonal," PESAT (2009) 3: 52-57.

Holy Bible. New International Version.

Khadijah Binti Hambali. "Konsep Salvation Menurut Agama Kristian: Satu Huraian Awal," Jurnal Usuluddin 10, no. 3, (1999): 43-50.

Lambert, J.C. "Cross." Dlm. James Hasting. Dictionary of the Bible. New York: Charles Scribner Son's, 1963.

Mariani Febriana. "Teologi Salib Martin Luther dan Implikasinya dalam Dunia Masa Kini,” JTA 12,no. 21 (2010): 36-54.

Markus Hildebrandt Rambe. "Penuntun Simbol-Simbol Ibadah Kristen Sebuah Ensiklopedi Dasar," Jurnal STT Intim Makassar 1 (2004): 19-42.

Martigny, J.A. "Cross". Dlm. James Hasting. Encyclopedia of Religion and Ethics. New York: Charles Scribner Son's, 1979. 
McGrath, Alister E. Christian Theology an Introduction. London: Wiley Blackwell Publication, 2011.

Rahmat S.H.. Dari Adam Sampai Muhammad Sebuah Kajian Mengenai Agama-agama. Kelantan: Pustaka Aman Press Sdn. Bhd, 1984.

Ries, Julien. "Cross". Dlm. Eliade. The Encyclopedia of Religion. New York: Macmillan Publishing Company, 1987.

Rogers, Laurice Diane. The Role of the Cross as a Transformative Symbol in Christian Counseling. Thesis Kedoktoran, The Southern Baptist Theological Seminary, 2005.

Safra, Jacob E. The New Encyclopedia Britanica. Chicago: Britanica, 2002.

Siede, B. "Cross". Dlm. Brown, Colin, Coenan, Lothar \& Beyreuther, Erich. The New International Dictionary of New Testament Theology. Michigan: Zondervan, 1975.

Tarpin, M. Ag. "Pandangan Kristen Tentang Dosa: Asal Muasa dan Cara Menbusnya," Jurnal Usuluddin XVI, no. 2, (2010): 221-233.

Thomas Ulun Ismoyo. "Penderitaan Sebagai Penyelamatan Studi Komparasi Antara Penderitaan Yesus Kristus dengan Penderitaan Iman Husayn,” Jurnal Teologi 1 (2012): 39-50. 